Research Article

\title{
Maternal and Fetal Outcome on Pregnancy in Advanced Maternal Age
}

\section{Luaran Maternal dan Fetal pada Kehamilan Ibu Usia Lanjut}

\author{
Sianty Dewi ${ }^{1}$, Ferry ${ }^{1}$, Eddy Toynbee ${ }^{2}$, Sandhy Prayudhana ${ }^{2}$ \\ ${ }^{1}$ Faculty of Medicine, University of Indonesia, Jakarta \\ ${ }^{2}$ Department of Obstetrics and Gynecology Tangerang General Hospital
}

\begin{abstract}
Objective: Pregnancy in advanced maternal age (AMA) was classified as high risk. The study aims to provide a better description of pregnancy outcome in AMA.

Method: The cross sectional study was to review the demography, medical and obstetrics problems, mode of delivery, maternal and fetal outcome in Tangerang General Hospital as a referral center in Banten. The data were taken from medical records of 35-year-old and above women age who delivered on the period of January to December 2014.

Result: The total number of delivery and live birth was 6,107 and 5,926 respectively, including $1,548(25.36 \%)$ pregnancies in AMA. The prevalence of grandmultiparities was $11.4 \%$. The average education level was mostly elementary. The prevalence of hypertension in pregnancy was $34.6 \%$. There was increasing trend of miscarriages from $10.8 \%$ in $35-40$-year-old group to $25 \%$ in above 45 year-old group. Pregnancy complications were higher consisting of $3.2 \%$ multifetal, $16.6 \%$ malpresentation, and $7.1 \%$ placenta previa. Cesarean section rate was $33.6 \%$. Maternal near-missed cases were 56 of 1000 and the maternal mortality rate (MMR) was 932 of 100,000 live births. The prevalence of stillbirth and perinatal mortality were $5.3 \%$ and $12.9 \%$; respectively.
\end{abstract}

Conclusion: Adverse maternal and fetal outcome were higher in AMA as it takes special attention and multidiscipline-approached care started from preconception, antenatal, preparation of delivery, and also postpartum care.

[Indones J Obstet Gynecol 2016; 4-3: 123-127]

Keywords: advanced maternal age (AMA), fetal outcome, maternal outcome, pregnancy

\begin{abstract}
Abstrak
Tujuan: Kehamilan ibu usia lanjut memiliki risiko tinggi. Rumah Sakit Umum (RSU) Tangerang adalah pusat rujukan di provinsi Banten, sehingga diharapkan penelitian ini dapat menggambarkan luaran kehamilan pada ibu usia lanjut.
\end{abstract}

Metode: Penelitian ini menggunakan studi potong lintang yang melakukan kajian pada karakteristik demografi, masalah medis, obstetri, metode persalinan, luaran fetal dan maternal di RSUD Tangerang sebagai pusat rujukan Provinsi Banten. Data diambil dari rekam medis kasus kehamilan ibu usia lanjut di RSUD Tangerang dari Januari 2014 sampai Desember 2014.

Hasil: Terdapat 6.107 persalinan, 5.926 kelahiran hidup di mana $1.548(25,36 \%)$ ibu usia lanjut. Sebanyak 11,4\% grandemultipara, pendidikan rata-rata SD. Prevalensi hipertensi 34,6\%. Abortus meningkat sebanding usia ibu, dari 10,8\% pada usia 35-40 tahun sampai $25 \%$ pada usia $\geq 45$ tahun. Komplikasi kehamilan lebih tinggi dari penelitian lain, yaitu kehamilan kembar 3,2\%, malpresentasi 16,6\% dan plasenta previa 7,1\%. Seksio sesarea sebanyak 33,6\% persalinan. Kejadian maternal near missed dan AKI yaitu 56 per 1000, dan 932 per 100.000 kelahiran hidup. Prevalensi kematian janin intrauterin dan perinatal adalah $5,3 \%$ dan $12,9 \%$.

Kesimpulan: Luaran maternal dan fetal yang tidak diinginkan sampai dengan kematian ibu dan janin lebih tinggi pada ibu usia lanjut, sehingga diperlukan perhatian dan penanganan khusus dimulai dari perencanaan kehamilan, asuhan antenatal, persiapan persalinan, dan asuhan nifas yang baik.

[Maj Obstet Ginekol Indones 2016; 4-3: 123-127]

Kata kunci: kehamilan ibu usia lanjut, luaran fetal, luaran maternal

Correspondence: Sianty Dewi. Email: siantyde@ukwms.ac.id

\section{INTRODUCTION}

Pregnancy in advanced maternal age (AMA) is generally defined as pregnancy in women aged 35 years old or older. ${ }^{1}$ The trend of delayed childbearing is increasing, especially in developed countries, since last decade. ${ }^{2}$ This situation also happened in Indonesia as it was reported by Indonesia Demographic Health Survey (IDHS) in 2013. ${ }^{3}$ This accelerating demographic shift becomes major clinical and public concern. ${ }^{4}$ Pregnancy in AMA is prone to have higher complications, whether it is caused by general degenerative process or decrease of reproductive function. ${ }^{5}$
Tangerang General Hospital is a tertiary and referral center in Banten as one of the most crowded provinces in Indonesia. ${ }^{3}$ Annual Report of Tangerang General Hospital in 2013 recorded 7,534 deliveries, including 1,683 (22.3\%) pregnancies in AMA. ${ }^{6}$ Therefore, this study aims to provide a better description of pregnancy outcome in AMA.

\section{METHODS}

The cross-sectional study reviewed the demography, medical and obstetrics problems, mode of delivery, maternal and fetal outcome in Tangerang General Hospital, Banten. The data were taken 
from medical records of patients with the inclusion criteria of 35 year-old and above women delivering in Tangerang General Hospital from January 1, 2014 to December 31, 2014. Data entry and analysis used Microsoft Excel 2010.

\section{RESULTS}

\section{The Characteristics of Patients}

There were 6,107 deliveries and 5,926 live births in Tangerang General Hospital from January 2014 to December 2014 . Of those, $25.3 \%$ or 1,548 cases were pregnancy in AMA. There were nineteen missing cases or incomplete medical records secondary to Death on Arrival (DOA) cases or transferred to other departments.

Table 1 described the advanced maternal age during pregnancy whereas the majority of cases were due to multiparities. While majority of patients were only completed elementary school and the average time was spent for schooling was around 8.27 years.

\section{Maternal Outcomes}

There were 38\% pregnancies with medical disorders. Hypertension was the most common medical disorders as 529 cases (34.6\%) followed by 17 cases $(1.1 \%)$ of diabetes, 1 case (0.1\%) of HIV and 33 cases $(2.2 \%)$ of other diseases.

Table 1. Maternal Age to Parity and Education Level

\begin{tabular}{|c|c|c|c|c|c|c|c|c|}
\hline \multirow[b]{2}{*}{ Age } & \multicolumn{3}{|c|}{ Parity } & \multicolumn{5}{|c|}{ Education level } \\
\hline & $\leq 1$ & $2-5$ & $6++$ & Less & Elm & JHs & SHs & HD1 \\
\hline $35-<40$ & 76 & 1060 & 103 & 22 & 546 & 404 & 238 & 29 \\
\hline Percent & 6.1 & 85.6 & 8.3 & 1.8 & 44.1 & 32.6 & 19.2 & 2.3 \\
\hline $40-<45$ & 10 & 195 & 61 & 5 & 124 & 51 & 61 & 25 \\
\hline Percent & 3.8 & 73.3 & 22.9 & 1.9 & 46.6 & 19.2 & 22.9 & 9.4 \\
\hline$\geq 45$ & 2 & 12 & 10 & 5 & 11 & 4 & 3 & 1 \\
\hline Percent & 8.3 & 50.0 & 41.7 & 20.8 & 45.8 & 16.7 & 12.5 & 4.2 \\
\hline \multirow[t]{2}{*}{ Total } & 88 & 1267 & 174 & 32 & 681 & 459 & 302 & 55 \\
\hline & 5.8 & 82.9 & 11.4 & 2.1 & 44.5 & 30.0 & 19.7 & 3.6 \\
\hline
\end{tabular}

\footnotetext{
Notes:

Less : not completed Elementary school

Elm : completed Elementary school

JHs : completed Junior High school

SHs : completed Senior High school

HD1 : Diploma and higher
}

Table 2. Maternal Age to Obstetrics Problems and Mode of Delivery

\begin{tabular}{|c|c|c|c|c|c|c|c|c|c|c|c|c|}
\hline \multirow[b]{2}{*}{ Age } & \multicolumn{3}{|c|}{ First Timester } & \multicolumn{5}{|c|}{ Second \& Third Trimester } & \multicolumn{4}{|c|}{ Mode of Delivery } \\
\hline & Ab & Ect & Mol & MuP & PS & MalP & PIP & PIA & Sp & CS & Vc & Fc \\
\hline $35-<40$ & 134 & 14 & 5 & 32 & 199 & 198 & 86 & 23 & 650 & 371 & 57 & 8 \\
\hline Percent & 10.8 & 1.1 & 0.4 & 2.6 & 16.1 & 15.9 & 6.9 & 1.8 & 59.8 & 34.3 & 5.2 & 0.7 \\
\hline $40-<45$ & 45 & 3 & 8 & 15 & 25 & 49 & 22 & 6 & 136 & 64 & 8 & 2 \\
\hline Percent & 16.9 & 1.1 & 3.0 & 5.6 & 9.4 & 18.4 & 8.2 & 2.2 & 64.8 & 30.5 & 3.8 & 0.9 \\
\hline$\geq 45$ & 6 & 0 & 0 & 2 & 2 & 7 & 0 & 0 & 10 & 7 & 0 & 1 \\
\hline Percent & 25.0 & 0 & 0 & 8.3 & 8.3 & 29.1 & 0 & 0 & 55.5 & 38.9 & 0 & 5.6 \\
\hline Total & 185 & 17 & 11 & 49 & 226 & 254 & 109 & 29 & 796 & 442 & 65 & 11 \\
\hline Percent & 12.1 & 1.1 & 0.7 & 3.2 & 14.8 & 16.6 & 7.1 & 1.9 & 60.7 & 33.6 & 4.9 & 0.8 \\
\hline $\begin{array}{ll}A b & : A \\
E c t & : E \\
M o l & : M \\
M u P & : M \\
P S & : P \\
M a l P & : M\end{array}$ & $\begin{array}{l}\text { on } \\
\text { c Pregn } \\
\text { Pregna } \\
\text { le Preg } \\
\text { us Scar } \\
\text { esentat }\end{array}$ & & $\begin{array}{l}P I P \\
P I A \\
S p \\
C S \\
V C \\
F C\end{array}$ & $\begin{array}{l}\text { : Placenta } \\
: \text { Placenta } \\
\text { : Spontane } \\
: \text { Cesarean } \\
: \text { Vacuum } \\
: \text { Forceps }\end{array}$ & $\begin{array}{l}\text { via } \\
\text { ruption } \\
\text { vagina } \\
\text { ction } \\
\text { raction } \\
\text { action }\end{array}$ & very & $\begin{array}{l}\text { *The nu } \\
\text { in the la } \\
\text { patient }\end{array}$ & $\begin{array}{l}\text { and } \\
\text { vard a } \\
\text { thave }\end{array}$ & $\begin{array}{l}\text { tage os } \\
\text { oeratin. } \\
\text { diagnos }\end{array}$ & $\begin{array}{l}\text { es were } \\
\text { ater re } \\
\text { the ab }\end{array}$ & $\begin{array}{l}\text { don } \\
\text { It } m \text { ompli }\end{array}$ & $\begin{array}{l}\text { agnosis } \\
\text { ne } \\
\text { one }\end{array}$ \\
\hline
\end{tabular}


Table 2 showed obstetric problems in the first trimester lead to nonviable conception and problems which revealed in later gestational age. The rate of CS was high (33.6\%) because AMA and multiparities had higher risk problems such as malpresentation, previous CS, placenta previa, placental abruption, and multiple pregnancy.

There were total of 66 maternal near-missed cases (56 in 1,000 live births) required special care in ICU or HCU on admission and there were 11 maternal mortality cases (the maternal mortality rate/MMR 932 per 100,000 live births).

\section{Fetal Outcomes}

Study of fetal outcomes on pregnancy in AMA showed regardless of spontaneous or medically indicated, premature delivery comprised $26.4 \%$ of all deliveries; while, term deliveries were occurred in 849 cases (58\%), serotines deliveries were in 13 cases $(0.9 \%)$, and the rest were less than 20 weeks which could be abortion, molar pregnancy, and ectopic pregnancy. As recorded, another severe outcome as fetal congenital anomaly was presented in 35 cases $(2.96 \%)$.

Table 3. Birth Weight

\begin{tabular}{lcc}
\hline \hline Birth weight (grams) & Cases & $\mathbf{\%}$ \\
\hline 500 - 999 & 28 & 2.2 \\
1000 - 1499 & 42 & 3.4 \\
1500 - 2499 & 188 & 15.0 \\
2500 - 3999 & 971 & 77.5 \\
4000 - 4499 & 21 & 1.7 \\
$4500+$ & 2 & 0.2 \\
Total & 1251 & 100.0 \\
Abortus, ectopic, molar, & 278 & \\
non-institutional delivery & & \\
Total & 1529 & \\
\hline \hline
\end{tabular}

The incidence of Extremely Low Birth Weight (ELBW), Very Low Birth Weight (VLBW), and Low Birth Weight (LBW) were $2.2 \%, 3.4 \%$, and 15\%; respectively. However, the incidence of macrosomia (>4000 grams) was $1.9 \%$. After excluding early pregnancy loss and non-institutional delivery, there were $5.3 \%$ intrauterine fetal death and $12.9 \%$ perinatal death.

\section{DISCUSSION}

The Age Specific Fertility Rate (ASFR) is the number of live births per 1,000 women in a specific age group for particular geographic area in the point of time annually. ${ }^{7}$ Age specific fertility rate (ASFR) for 35-year-old and above Indonesian women was $16.76 \%$; however, this study reported the prevalence was $25.3 \% .{ }^{8}$ Higher proportion of pregnancy in AMA in this institution showed that this group had major clinical and public health problem because AMA is consistently associated with adverse pregnancy outcomes.

In this study, $5.8 \%$ of pregnancy in AMA experienced conceiving for the first time. The rate was lower than in Europe $(11 \%){ }^{2}$ It showed that pregnancy in AMA in this institution was caused by multiparity compared to delayed childbirth. ${ }^{9}$ Indonesia Demographic Health Survey (IDHS) 2013 reported the average number of children for 40-49 year-old women were 3.2 in Indonesia, 3.8 in Banten, and 4.8 in this institution. ${ }^{3}$

In 2013, the average duration of schooling for more than 15 years was 8,62 in Banten Province. ${ }^{10}$ Most patients had the educational level only elementary graduated with the average duration of schooling was 8.27 years. The patients' educational level was under the average of Banten province whereas the older population had lower education level.

Education is very important and it contributed to society behavioral changes toward personal or family health. Apart from the formal education, preventive health knowledge needs to be improved through health counseling and seminar for pregnant lady or her family members. For example, Chile was able to reduce $93.8 \%$ MMR in 50 years drastically from 293.7 to 18.2 per 100,000 . Learning all contributing factors, women educational attainment was the main factors. Educational status will affect birth rate, delivery process attended by skill professional health, sanitation, and personal hygiene. ${ }^{11}$

Medical disorders in this study were 38\% consisting of $34.6 \%$ cases of hypertension. However, the prevalence of hypertension in pregnancy was reported to be $10-15 \%$ in England. ${ }^{2}$ It was two to three times more frequent. Therefore, the further prospective study should be conducted to determine the causes of this event. The prevalence of diabetes on pregnancy in AMA was $1.1 \%$, as this 
number was lower than in United Kingdom (2-5\%) in spite of same screening guideline between Indonesia and United Kingdom. ${ }^{2}$ This finding was not correlated with the fact that being older and Asian had more prone to diabetes. Diabetes screening may not performed well in daily practice.

This study found $0.1 \%$ of pregnancy in AMA suffering from HIV. In Indonesia, the HIV prevalence in pregnancy was $0.38 \%$ which was reported by Ministry of Health (MOH) in 2011. The HIV screening should be offered to all pregnant women as HIV in society like iceberg phenomena whereas the actual incidence is higher. ${ }^{12}$

There was also an increasing trend of miscarriages from $10.8 \%$ in $35-40$ years old, $16.9 \%$ in 40-45 years old to $25 \%$ after 45 years old. These numbers were lower than other countries such as Denmark which had $24.6 \%, 51 \%$, and $93.4 \%$; respectively, because of poor documentation and low educational level in society. ${ }^{2}$

In this study, the prevalence of ectopic pregnancy was $1.1 \%$. This was also documented lower than other countries such as Denmark which showed $1.4 \%$ at the age of 21 and $6.9 \%$ at the age of more than $44 .^{2}$

Molar pregnancy in this study was reported 4 per 1,000 at the age of $35-40$ and 30 per 1,000 at the age of 40-45. This number was much higher than 1 per 1,000 in United Kingdom. ${ }^{13}$

Multiple pregnancy was reported 32 per 1,000 live births which was three times higher on pregnancy in AMA than younger women. However, it was lower than other developed countries as in developed countries had higher Artificial Reproductive Therapy (ART) for pregnancy in AMA, such as in England which was resulting 110 per 1,000 live births. $^{7}$

The prevalence for placenta previa was $7.1 \%$ which showed almost twice than reported in Europe, such as $3.7 \%$ in Turkish because pregnancy in AMA in Indonesia had the characteristics of higher parity, CS, and curettage. They were the risk factors for placenta previa. ${ }^{14}$

In 1995-2005, Yaniv, et al. reported higher risk of fetal malpresentation in nulliparous in AMA group $(6.9 \%$ in younger than 35 year-old women and $12.4 \%$ in AMA). ${ }^{15}$ In this study, the result described $16.6 \%$ of fetal malpresentation cases. Higher fetal malpresentation may be caused by multiparity as the tonus and elasticity of abdominal wall were malformed by age, trauma, and stretch due to repeatedly being pregnant.

Caesarean section rate in this study pointed out $33.6 \%$. Majority of the causes were due to cephalopelvic disproportion, previous CS, malpresentation, and fetal distress. ${ }^{16}$ Previous CS was documented to be $14.8 \%$ in AMA and $4.9 \%$ in younger women. ${ }^{6}$

The maternal mortality rate (MMR) in Tangerang general hospital was calculated to be 607.5 per 100,000 live births equal to 1.7 times than MMR in Indonesia globally which counted for 359 per 100,000 live births. ${ }^{10}$ This was occurred due to the Tangerang General hospital is a tertiary hospital in Banten Province. As a comparison to other tertiary hospitals in a developing country such as Western Maharashtra Hospital India in 2001-2010, the MMR was $302.23 / 100,000$ live births equal to 1.42 times higher than MMR globally (212 per 100,000 live births). ${ }^{17}$

There were 66 maternal near-missed cases (55.9 in 1,000 live births) that required special care in ICU or HCU during admission, contributing to 11 maternal mortality cases (MMR 932.2 per 100,000 live births in AMA population). It showed that AMA carries high risk for complications.

There was no difference for prevalence of congenital anomaly in older women for this study compared to general population since fetal anomaly and chromosomal screening was not offered to the patients. Premature delivery was 55 per 1,000 deliveries lower than reported by Laopaiboon, et al. which indicated 67 per 1,000 delivery. ${ }^{1}$ This was due to the limitation of NICU availability in the observed hospital.

There was no difference for prevalence of congenital anomaly in older women, while the prevalence of stillbirth in AMA was twice than younger women. ${ }^{18}$ The perinatal mortality in AMA population was $12.9 \%$. This data was associated with study by Reddy and Ko, et al. in 2001 that they showed the increment of IUFD was 1.28 times in 35-39 year-old women and 1.79 times in 40 yearold women compared to younger women. ${ }^{19}$

The limitations of the study were not included all AMA cases in population; as retrospective study highly depended on consistency and accuracy of documentation. Incorrect entries may lead to wrong conclusion. 


\section{CONCLUSIONS}

Adverse maternal and fetal outcomes such as maternal near-missed, maternal death, stillbirth, and perinatal mortality were higher in AMA, as it needs special attention and multidiscipline-approached care started from preconception, antenatal, preparation of delivery, and postpartum care.

A meticulous documentation is vital for formulating epidemiological and management strategies that may have considerable implications for the provision of resources in the obstetric and pediatric specialties.

It is also useful for hypotheses-generating studies, or studies directed at one specific association between risk factors and maternal or fetal outcomes in order to confirm or refute possible association. This is in view of the future planning and implementation of the policies and guidelines in the management of advanced maternal age as high risk group.

\section{REFERENCES}

1. Laopaiboon M, Lumbiganon P, Intarut N, et al. WHO Multicountry survey on Maternal Newborn Health Research Network, Advanced maternal age and pregnancy outcome: a multicountry assesment. BJOG. 2014; 121(Suppl I): 49-56.

2. Mills TA, Lavender T. Advanced Maternal Age. Obstet Gynecol Reprod Med 2014; 24(3): 85-90.

3. BKKBN, BPS, KEMENKES. Indonesia Demographic and Health Survey 2012. In: BPS, BKKBN, Kemenkes-MOH, 2013 II, editors. Jakarta, Indonesia: Ministry of Health; 2013: 2470.

4. Valadan M, Tanha FD, Sepahi A. Pregnancy Outcomes in Women of Advanced Maternal Age. J Fam Reprod Health. 2011; 5(2): 59-63.

5. Suswadi. Penyulit Kehamilan dan Persalinan pada Wanita Usia Tua. Obstet Ginekol. 2000: 35-9.

6. OBGIN. Laporan Tahunan Obstetri dan Ginekologi RSU Tangerang 2014. 2015: 39-43.
7. Cunningham FG, Leveno KJ, Bloom SL, S et al. Williams Obstetrics. 2014: 759-61.

8. Sakti G. Rencana Aksi Nasional Percepatan Penurunan Angka Kematian Ibu di Indonesia. 2013: 57-61.

9. Yogev Y, Melamed N, Tenenbaum K. Pregnancy outcome at extremely advanced maternal age. Am J Obstet Gynecol. 2010; 203(558): e1-7.

10. Supriyantoro. Profil Kesehatan Indonesia 2013. Jakarta: Kementerian Kesehatan Republik Indonesia; 2014. 3-29, 7185.

11. Koch E, Throp J, Bravo M, et al. Women Education Level, Maternal Health Facilities, Abortion Legislation and Maternal Deaths: A Natural Experiment in Chile from 1957 to 2007. PLoS One. 2012; 7(5): e36613.

12. KEMENKES. Pedoman Nasional Pencegahan Penularan HIV dari Ibu ke Anak 2011. Jakarta: Direktur l Pengendalian Penyakit dan Penyehatan Lingkungan; 2011: 113-8.

13. Tse KY, Chan KK, Tam KF, et al. Current management of gestational trophoblastic disease. Obstet Gynecol Reprod Med. 2014; 25(1): 12-21.

14. Baser E, Seckin KD, Erkilinc S, Karsh MF, Yeral IM, Kaymak 0 , et al. The impact of parity on perinatal outcome in pregnancies complicated by advanced maternal age. J TurkishGerman Gynecol Assoc. 2013; 14: 205-9.

15. Yaniv SS, Levy A, Wiznitzer A, Holcberg G, Mazor M, Sheiner E. A significant linear association exists between advanced maternal age and adverse perinatal outcome. Arch Gynecol Obstet. 2010; 283: 755-9.

16. Ecker JL, Chen KT, Cohen AP, Riley LE. Increased risk of cesarean delivery with advancing maternal age: Indication and associated factors in nulliparous women. Obstet Gynecol Reprod Biol. 2001: 883-7.

17. Murthy B, Murthy M, Prabhu P. Maternal Mortality in a Tertiary Care Hospital: A 10-year Review. Int J Preven Med. 2013; 4(1): 105-9.

18. Karabulut A, Ozkan S, Bozkurt AI, et al. Perinatal outcomes and risk factors in adolescent and advanced age pregnancies: Comparison with normal reproductive age women. J Obstet Gynecol. 2013: 346-50.

19. Reddy UM, Ko C-W, Willinger M. Maternal age and the risk of stillbirth throughout pregnancy in the United States. Am J Obstet Gynecol 2006; 195: 764-70. 